\begin{tabular}{|l|l|l||}
\hline \multicolumn{2}{|c|}{ PublisherInfo } \\
\hline \hline PublisherName & $:$ & BioMed Central \\
\hline \hline PublisherLocation & $:$ & London \\
\hline \hline PublisherImprintName & $:$ & BioMed Central \\
\hline \hline
\end{tabular}

\title{
Putting an end to chromosome stability
}

\begin{tabular}{||l|l|l||}
\hline \multicolumn{2}{|c|}{ ArticleInfo } \\
\hline \hline ArticleID & $:$ & 3971 \\
\hline \hline ArticleDOI & $:$ & $10.1186 /$ gb-spotlight-20010206-01 \\
\hline \hline ArticleCitationID & $:$ & spotlight-20010206-01 \\
\hline \hline ArticleSequenceNumber & $:$ & 42 \\
\hline \hline ArticleCategory & $:$ & Research news \\
\hline \hline ArticleFirstPage & $:$ & 1 \\
\hline \hline ArticleLastPage & $:$ & 2 \\
\hline \hline & & RegistrationDate : 2001-02-06 \\
ArticleHistory & $:$ & OnlineDate $\quad$ 2001-02-06 \\
\hline \hline ArticleCopyright & $:$ & BioMed Central Ltd2001 \\
\hline \hline ArticleGrants & $:$ & \\
\hline \hline ArticleContext & $:$ & 130592211 \\
\hline \hline
\end{tabular}




\section{Jonathan B Weitzman}

Email: jonathanweitzman@hotmail.com

The ends of vertebrate chromosomes are protected by telomeric structures containing several kilobases of short repeated sequences (TTAGGG). In the January Molecular and Cellular Biology Kilburn et al. describe their investigation of the effect of telomeric repeats inserted at defined intrachromosomal locations (Mol Cell Biol 2001, 21:126-135). They used site-specific recombination to place an 800 nucleotide fragment from a functional vertebrate telomere repeat, in either orientation, within a specified gene intron in $\mathrm{CHO}$ cells. They found that the interstitial telomere repeat induced genomic instability and extensive rearrangements (30-fold above background). They observed no chromosomal truncations, seeding of new telomeres or enhanced homologous recombination and little affect on gene expression. Hence, interstitial telomeric repeats act as destabilizing elements and may contribute to the rearrangements seen in cancer cells following chromosome fusions.

\section{References}

1. Telomeres and their control.

2. Molecular and Cellular Biology, [http://intl-mcb.asm.org] 